\title{
The Ideal and the Real: interior linings in 1930s New Zealand homes
}

\author{
Eva Forster-Garbutt, PhD candidate, Victoria University, Wellington
}

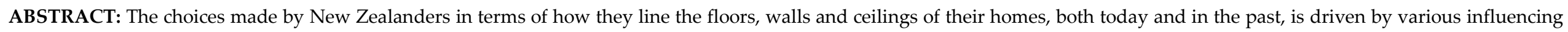

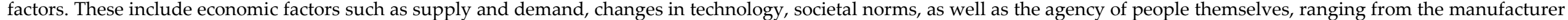

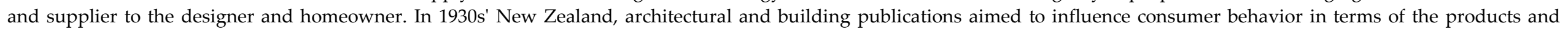

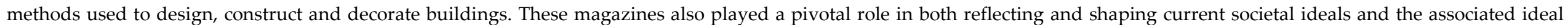

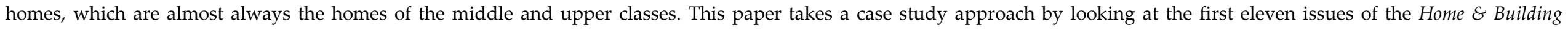

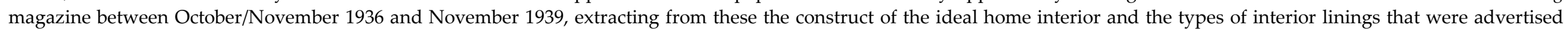

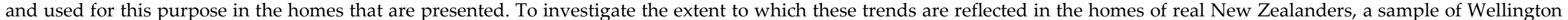
building consents and historical interior photographs available through DigitalNZ are used.

Given the rich published history on New Zealand's architecture it is surprising that little has been written about their interiors, ${ }^{1}$ including the decorative linings, furnishings, fittings and ornamentation used to transform the physical structure of a house into a home. Given the greater flexibility, scope of personal choice and the ease of fitting out and renovating interiors over exteriors, it is often these aspects of the home that were, and still are, the focus of homeowners to express their tastes, identity and social aspirations. ${ }^{2}$ Linings fixed or applied to the floors (carpet,

${ }^{1}$ Publications dedicated to New Zealand interiors include: lloyd-Jenkins At Home; Petersen New Zealanders at Home; Brookes At Home in New Zealand; Cottrell Furniture; Leach Kitchens; Drummond \& Drummond At Home in New Zealand.

${ }^{2}$ Noted by Brookes "A Sense of Place" p 3 and Leonard et al. "Presenting and Creating Home" p 97. linoleum, vinyl), walls (wallpaper, paint) and ceilings, are often the first components of the interior that are selected, both for new builds and existing home renovations, to form the background for the moveable items that are used to furnish and embellish rooms. Linings also represent the aspect of the interior that is changed less frequently. ${ }^{3}$ As such, conscious and often informed decisions are involved in their selection. The choice of linings is dependent on a complex web of influencing factors which includes what is available and affordable, the advice received from professionals, family and friends, and ideas extracted from a range of media sources. A

${ }^{3}$ Brand How Buildings Learn pp 12-13 categorises linings as part of the "scenery" layer of a building, which is changed on average every 5 to 7 years. It is likely that in the real setting of the home these changes may occur less frequently. study by Leonard et al. of 41 Christchurch homeowners between 1996 and 2004, illustrated how the available popular and building trade print media "both reflect and shape taste and thus create normative images and ideals about what constitutes "home"," stating that "the media therefore act to present the home in "ideal" terms." 4 This is as true in the construction of the ideal New Zealand home in the contemporary context, as it was in the past.

This paper seeks expand our knowledge of decorative interior linings used during the 1930s in New Zealand homes, by looking at the visual and textual references to these within the pages of Home $\mathcal{E}$ Building, one of

${ }^{4}$ Leonard et al. "Presenting and Creating Home" pp 9899 
this country's first popular architectural magazines, and to compare the linings used in the "ideal" homes represented within its pages, to those used within "real" New Zealand homes based on a sample of photographs and building permits.

\section{Methodology}

A qualitative content analysis of the advertising, articles and images associated with interior lining products and styles was undertaken for the eleven issues of the Home $\mathcal{E}$ Building magazine published between October/November 1936 and November 1939. Close attention was also paid to explicit and implicit references to the broader economic and socio-cultural factors in play at the time and the stance of the editors, as both influenced the ideal homes that were communicated to the readers and the content that was included.

For the purposes of this paper, a small sample of homes of everyday New Zealanders was selected to provide an initial view of the linings and trends that were used in these. Twelve building permits issued in Wellington for the construction of domestic dwellings between 1937 and 1939, four for each year, were randomly selected from those that have

\begin{tabular}{|c|c|c|c|c|c|c|c|}
\hline Date & Owner & Architect & Address & $\begin{array}{l}\text { Est. } \\
\text { Value }\end{array}$ & Type & $\begin{array}{l}\text { Size } \\
(\mathrm{sq} \mathrm{ft})\end{array}$ & WCC Ref \\
\hline Aug-37 & $\begin{array}{l}\text { C R Johnston } \\
\text { Esq }\end{array}$ & Not stated & Moxham Avenue & $£ 1,900$ & $\begin{array}{l}\text { Two storey, } 3 \\
\text { bedrooms }\end{array}$ & $\begin{array}{l}\text { Not } \\
\text { stated }\end{array}$ & 00056-B16931 \\
\hline Sep-37 & A E Tilley & Not stated & Northland Road & $£ 1,478$ & $\begin{array}{l}\text { Single storey, } 3 \\
\text { bedrooms }\end{array}$ & 1300 & 00056-B17042 \\
\hline Dec-37 & Mr F Houri Esq & A Garnett & $\begin{array}{l}\text { Beatty Avenue, } \\
\text { Karori }\end{array}$ & $£ 900$ & $\begin{array}{l}\text { Single storey, } 3 \\
\text { bedrooms }\end{array}$ & $\begin{array}{l}\text { Not } \\
\text { stated }\end{array}$ & 00056-B17320 \\
\hline Dec-37 & J J Craig Esq & Not stated & $\begin{array}{l}\text { Messines Road, } \\
\text { Karori }\end{array}$ & $£ 1,410$ & $\begin{array}{l}\text { Single storey, } 3 \\
\text { bedrooms }\end{array}$ & 1570 & $\begin{array}{l}00056-199- \\
\text { B17329 }\end{array}$ \\
\hline Apr-38 & A D Bennett & Robin Hood & $\begin{array}{l}\text { Stratmore Park, } \\
\text { Miramar South }\end{array}$ & $£ 1,250$ & $\begin{array}{l}\text { Single storey, } 3 \\
\text { bedrooms }\end{array}$ & $\begin{array}{l}\text { Not } \\
\text { stated }\end{array}$ & 00056-B17985 \\
\hline May-38 & $\begin{array}{l}\text { Mr E A } \\
\text { Bullinger } \\
\end{array}$ & Not stated & $\begin{array}{l}\text { Cashmere Avenue, } \\
\text { Khandallah }\end{array}$ & $£ 1,192$ & $\begin{array}{l}\text { Single storey, } 2 \\
\text { bedrooms }\end{array}$ & 1200 & 00056-B17839 \\
\hline May-38 & Mr G Natoli & J G Mulling & $\begin{array}{l}\text { Trent Street, Island } \\
\text { Bay }\end{array}$ & $£ 1,337$ & $\begin{array}{l}\text { Single storey, } 3 \\
\text { bedrooms }\end{array}$ & 1280 & 00056-B17893 \\
\hline Nov-38 & $\begin{array}{l}\text { A R \& G H } \\
\text { Craig }\end{array}$ & $\begin{array}{l}\text { Dawson \& } \\
\text { King }\end{array}$ & $\begin{array}{l}\text { Bengal Street, } \\
\text { Khandallah }\end{array}$ & $£ 1,900$ & $\begin{array}{l}\text { Two storey, } 2 \\
\text { bedrooms }\end{array}$ & 1500 & 00056-B18489 \\
\hline Jan-39 & H Burkett Esq & Not stated & Coates Street & $£ 950$ & $\begin{array}{l}\text { Single storey, } 2 \\
\text { bedrooms }\end{array}$ & $\begin{array}{l}\text { Not } \\
\text { stated }\end{array}$ & 00124-554-391 \\
\hline Apr-39 & Mrs C Robertson & H A Algar & Darlington Road & $£ 1,025$ & $\begin{array}{l}\text { Single storey, } 3 \\
\text { bedrooms }\end{array}$ & 1100 & 00056-B19127 \\
\hline Jun-39 & Mrs I B Bucholz & $\begin{array}{l}\text { Edmund } \\
\text { Anscombe \& } \\
\text { Associates }\end{array}$ & 90 Oriental Parade & $£ 5,022$ & $\begin{array}{l}\text { Two storey, } 4 \\
\text { bedrooms }\end{array}$ & 1716 & 00056-B19392 \\
\hline Jun-39 & $\begin{array}{l}\text { Mrs Mary } \\
\text { Coppock }\end{array}$ & A P Page & $\begin{array}{l}94 \text { Tiber Street, } \\
\text { Island Bay }\end{array}$ & $£ 960$ & $\begin{array}{l}\text { Single storey, } 2 \\
\text { bedrooms }\end{array}$ & 960 & $\begin{array}{l}00056-229- \\
19363\end{array}$ \\
\hline
\end{tabular}

Table 1. Sample of 12 building permits for dwellings in Wellington between 1937 and 1939.

been digitised by the Wellington City Council Archive (Table 1). This represents a small fraction of the 945 building permits for new dwellings issued during this period, of which 258 are digitised. In the sample, four of the single storey homes were constructed under $£ 1,025$, with a further five constructed below $£ 1,500$. A couple of two-storey residences in the sample were constructed below $£ 2,000$, with the two-storey four-bedroom (include a maid's room) home of Mrs IB Buchholz at 90 Oriental Parade, designed by Edmund Anscombe, constructed for just over $£ 5,000$, representing the upper-end of homes constructed during this period. Aside from the flat-roofed modernist home of Mrs 


\begin{tabular}{|c|c|c|c|c|}
\hline Date & Room & Location & Title & Reference \\
\hline 1930s & $\begin{array}{l}\text { Drawing } \\
\text { room/Lounge }\end{array}$ & Auckland District & $\begin{array}{l}\text { Interior design of living- } \\
\text { dining room in domestic } \\
\text { dwelling }\end{array}$ & 13-2206 (MOTAT) \\
\hline 1930s & Dining Room & Auckland District & $\begin{array}{l}\text { Interior design of living- } \\
\text { dining room in domestic } \\
\text { dwelling }\end{array}$ & 13-2263 (MOTAT) \\
\hline 1930s & $\begin{array}{l}\text { Drawing } \\
\text { room/Lounge }\end{array}$ & Auckland District & $\begin{array}{l}\text { Interior design of living room } \\
\text { in domestic dwelling }\end{array}$ & 13-2159 (MOTAT) \\
\hline 1930s & Hall & Unknown (Wellington?) & No title & 1/1-015757-F (Alexander Turnbull) \\
\hline 1930s & Kitchen & Hamilton District & $\begin{array}{l}\text { Ellis \& Burnand - kitchen } \\
\text { interior }\end{array}$ & $\begin{array}{l}\text { HCL_07365 (Hamilton City } \\
\text { Libraries) }\end{array}$ \\
\hline $\begin{array}{l}1930- \\
1939\end{array}$ & Dining room & Auckland District & Interiors & $\begin{array}{l}\text { 1370-U024-01 (Auckland Libraries } \\
\text { Heritage Collection) }\end{array}$ \\
\hline 1932 & Kitchen & Unknown (Wellington?) & Detail of a kitchen interior & 1/1-015728-F (ATL) \\
\hline c1937 & Hall & Wellington & Interior of private home & C.002736 (Te Papa) \\
\hline c1937 & Dining Room & Unknown (Wellington?) & Interior of private home & C.002734 (Te Papa) \\
\hline c1937 & $\begin{array}{l}\text { Drawing } \\
\text { room/Lounge }\end{array}$ & Unknown (Wellington?) & Interior of private home & C.002737 (Te Papa) \\
\hline $\begin{array}{l}1937- \\
38\end{array}$ & $\begin{array}{l}\text { Dining } \\
\text { Room/lounge }\end{array}$ & New Plymouth & Leech, Interior of House & SW1931-1940.10487 (Puke Ariki) \\
\hline 1938 & $\begin{array}{l}\text { Drawing } \\
\text { room/Lounge }\end{array}$ & Easdale Street, Wellington & $\begin{array}{l}\text { View of part of the Living } \\
\text { room in the Sutch House }\end{array}$ & $\begin{array}{l}\text { PAColl-5870-1-08 (Alexander } \\
\text { Turnbull) }\end{array}$ \\
\hline 1938 & Kitchen & Unknown (Wellington?) & Kitchen interior & 1/1-015928-F (Alexander Turnbull) \\
\hline c1938 & Drawing Room & Unknown (Wellington?) & $\begin{array}{l}\text { Three people in a drawing } \\
\text { room }\end{array}$ & 1/1-017566-F (Alexander Turnbull) \\
\hline 1939 & $\begin{array}{l}\text { Drawing } \\
\text { room/Lounge }\end{array}$ & Auckland District & House Interior - living room & 1370-U024-04 \\
\hline 1939 & Kitchen & Totara Park, Manurewa & No title & $\begin{array}{l}\text { Footprints } 03184 \text { (Auckland Council } \\
\text { Libraries) }\end{array}$ \\
\hline
\end{tabular}

Table 2. Sample of 16 photographs of New Zealand domestic interiors dating to the 1930s.

Bucholz and the Art Deco style home of $\mathrm{Mr}$ Houri Esq, the exteriors of the remaining homes ranged widely, from unique
A shortcoming of the specifications and plans submitted with building permits is that these mostly do not describe the patterns, textures or colours of linings. This is why a sample of photographs showing domestic interiors of the 1930s from around New Zealand was selected from those available through DigitalNZ. While the black and white photographs of the time do not provide us with information on the product types and colours of linings, patterns and textures are discernible as are the ways in which linings were combined. Several searches were undertaken for images, filtering by the 1930s. ${ }^{5}$ A total of 1,715 images matched these terms. ${ }^{6}$ Only photographs that could be securely dated to the 1930s, especially the latter half of the decade, and those which showed interiors of actual homes (rather than advertising or commercial premises) were selected. The sample consists of 16 photographs. Table 2 provides details of these.

A shortcoming of using historic photographs is that these do not allow us to firmly date

${ }^{5}$ Search terms used: "interior(s)," "bathroom," "kitchen," "laundry," "dining room," "living room," "drawing room," "bedroom" and "parlour."

${ }^{6}$ Some of these represent duplicates, based on the same term appearing in one image. 
when a lining was installed, unless the description accompanying the images states the interior is of a new or recently decorated home. However, historic photographs provide us with one of the best visual insights into past New Zealand homes, and are the source most frequently used by historians and architectural historians. ${ }^{7}$

To expand on this research, and to add information on the manufacturers of linings, the products available and used at a certain time, and their materiality (composition, textures, colours, patterns), samples of linings contained in public and private collections in New Zealand, ${ }^{8}$ and physical evidence of linings in standing, or formally standing, homes can be used. ${ }^{9}$ It is these avenues of

${ }^{7}$ lloyd-Jenkins At Home; Petersen New Zealanders at Home; Brookes At Home in New Zealand.

${ }^{8}$ New Zealand collections of interior linings include Heritage New Zealand Pouhere Taonga's (HNZPT) wallpaper collection, Te Papa's collection of wallpaper and linoleum, the Martin Hill Collection of wallpaper, linoleum and building material samples held by the Victoria University of Wellington (VUW), MTG Hawkes Bay collection of Art Deco wallpapers, and wallpaper samples extracted from Nairn's cottage held by the Museum of Wellington.

${ }^{9}$ This includes HNZPT properties, other public or privately-owned historic homes, and pre-1900 homes investigated and recorded by archaeologists prior to enquiry that I will also be using for my doctoral research on decorative interior linings of the Victorian and Edwardian period (1837-1914) in New Zealand.

\section{Home \& Building: Background, mission and readership}

A magazine devoted to the interests of all who love homes and gardens or who are interested in architecture and buildings. ${ }^{10}$

The first issue of what was to become Home $\mathcal{E}$ Building, was published with the title Building Today in October/November 1936 under the auspices of the Auckland Branch of the New Zealand Institutes of Architects (NZIA). After renaming the magazine to Home and Building To-day in the second issue, the name Home $\mathcal{E}$ Building was adopted by November 1937, when this became the national magazine of the NZIA. Home \& Building was the only periodical devoted to the regular publishing of New Zealand architecture until the late 1950s, ${ }^{11}$ and is considered by Clark and Walker as one of the first notable publications

their demolition as part of the statutory archaeological authority process administered by HNZPT.

${ }^{10}$ Purpose of the Home and Building magazine from the first issue.

${ }^{11}$ Clark \& Walker "Book, House, Home" p 208. on architecture in this country, ${ }^{12}$ which sought to bridge the gap between the architectural profession and popular discourse, between "those who thought about houses [architects] and those who thought of homes [owners]."13

The content of the magazine is highly visual, providing advertising and photographs of newly constructed or renovated buildings alongside articles describing these and the products used, techniques and materials for home improvements, as well as topical architectural and broader issues selected by the editors. While a large proportion of the homes illustrated are the stylish homes of the more well-to-do, ${ }^{14}$ more modest homes are also presented to extend the appeal, in the words of the editors, to "all sections of the community"15 and to "make good design practical for those that are not wealthy."16

The aim of the magazine was to place the work of architects and the value of this in the public realm during a time when architects were struggling to get private contracts, as

\footnotetext{
${ }^{12}$ Clark \& Walker Looking for the Local p 12.

${ }^{13}$ Clark \& Walker "Book, House, Home" p 208.

${ }^{14}$ Brookes \& Shaw "Constructing Homes" p 203.

15 "[untitled]" p 3.

${ }^{16}$ Beatson \& Crookes "Editorial [February 1939]" p 7.
} 
most homes were designed by builders. ${ }^{17}$ The focus was on promoting and portraying modern architecture, with content curated to reflect this by the first editors Ronald Beatson and C Irwin Crookes, both modernist architects. ${ }^{18}$ To spread this mission to a wide and diverse readership (and to keep the advertisers happy) the magazine was initially distributed free of charge through the local NZIA branches and was provided for the reading and waiting rooms in libraries, doctors' practices, accountant offices and dentists. While the magazine could also be purchased from newsagents for a reasonable price, very few issues of the magazine were distributed by this means. ${ }^{19}$ It is therefore likely that homeowners across the country, and from a variety of backgrounds, will have flipped through the pages of Home $\mathcal{E}$ Building between 1936 and 1939 to gather ideas of the designs and types of products and items to use for the construction or renovation of their home.

17 Shaw \& Brookes "Constructing Homes" p 201. ${ }^{18}$ Lloyd-Jenkins At Home p 77; Clark \& Walker Looking for the Local pp 14-16.

${ }^{19}$ In 1941, only 400 of the total 10,000 copies of the magazine were sold through news agents, and there

were only 60 subscribers, Brookes \& Shaw "Constructing Homes" p 201
Home \& Building: shaping the ideal home

Before considering the different lining products that were used within the homes in Home \& Building, it is important to briefly describe the architectural and lifestyle ethos propounded by the magazine, as this will have had an effect on the homes selected for the magazine, as well as reflecting the design and lifestyle influence promoted to its readers.

Terms such as "plain," "simplicity," "minimalist" and "modern" are frequently used to describe the virtues of individual products, such as plain carpets, drapes and painted walls, ${ }^{20}$ and uncluttered interior spaces. ${ }^{21}$ These are the hallmarks of the architectural styles of the time referred to as modernist and modernistic (Art Deco). ${ }^{22}$ There was a clear desire to distance oneself from the old homes of the settlers by transforming these through renovations, or to build new and modern homes. ${ }^{23}$ In terms of interior design, there was a call for a cohesive interior

${ }^{20}$ Beatson "A Charming New Home at Auckland" p 15; Gosset "Make way for Modern" $\mathrm{p} 37$.

21 "A Portfolio of Modern New Zealand Homes" p 24; Beatson \& Crookes "Editorial" [February 1939] p 7; "A house on a hill" p 16.

${ }^{22}$ lloyd-Jenkins At Home pp 75-87.

${ }^{23}$ Beatson \& Crookes "Editorial [January 1937]" p 7; "A Modernised homestead" p 31. design approach throughout all rooms of the home, and for these to reflect and harmonise with the home's exterior appearance and style. $^{24}$ Advertisements for the home furnishing sections in department stores frequently include the word "harmony" with reference to furnishings. ${ }^{25}$

These shifts in architecture that were occurring in New Zealand, are also reflected in an express desire within the magazine for a more informal way of life, through comments such as "we are not severe and formal people these days, nor should our living rooms suggest this,"26 and living rooms "built not as showy fitments, but to meet the actual requirements of living." 27 Comfort in the fittings and furnishings of the home became increasingly important through statements such as "Always furnish for comfort, both physical and artistic, and you can never be disappointed in the results." 28

Coupled with a less formal lifestyle and

\footnotetext{
${ }^{24}$ Tecta "Orderliness" p 34.

${ }^{25}$ Milne \& Choyce Ltd "Backgrounds for Modern Living" p 22; Andrews \& Clark "Striking the Notes" p 37.

26 "Evolution or Revolution" p 43.

27 "Cintra" p 19.

28 Tecta "Orderliness" p 34.
} 
reflecting the declining presence of domestic servants within the home, ${ }^{29}$ emphasis was placed on homes to be more practical, convenient and hygienic through comments such as "there is a growing demand for comfort and efficiency, a sure sign that we are definitely moving forward in the science of living." ${ }^{30}$ This is reflected in statements extoling the convenience of open plan living, ${ }^{31}$ the promotion of labour saving domestic appliances, ${ }^{32}$ and the use of new "vermin and dust proof linings,"33 such as plaster board, that largely replaced the use of sarking and scrim in homes during the 1920 s and ' 30 s. ${ }^{34}$

Aligned with a break in traditional and more structured approaches to architectural design, the magazine encourages its readers to exert

29 "Cintra" p 19 states the "servant problem is just one reason for cleaner and more efficient homes." Between 1936 and 1945 domestic service disappeared in New Zealand, in line with trends occurring elsewhere in the Western world, Macdonald "Strangers at the Hearth" $p$ 56.

${ }^{30}$ Beatson \& Crookes "Editorial [November 1937]" p 7. ${ }^{31}$ Combined living and dining rooms became a feature of interior planning, such as for the Garden Flats in Mission Bay, "Garden Court" p 22.

32 "Esse Ltd "Better Cooking!" p 14.

${ }^{33}$ Beatson \& Crookes "Editorial [January 1937]" p 7.

${ }^{34}$ Ashford The Bungalow in New Zealand $\mathrm{p} 72$. the requirements for their home with the designer, and to express their identity through its design and furnishing. An editorial on the role of the architect in design mentions that "different people need what serves the purpose of their different modes of life."35 Advertisements for the home furnishing sections of department stores, and wallpaper and paint supplier Guthrie Bowron, promote their services to clients by encouraging them to express their identity and originality in their homes. ${ }^{36}$ The role of women in this process is acknowledged through several articles by columnist Helen M Gossett which provide tips on home renovations, and in advertisements for kitchen and laundry appliances referring to women's demands for modern appliances, ${ }^{37}$ and those for home furnishing departments, that depict or mention women as the home makers and deciders. $^{38}$

${ }^{35}$ Beatson \& Crookes "Editorial [February 1939]" p 7.

${ }^{36}$ Guthrie Bowron \& Co Ltd "Life's a matter of environment" p 35; Milne \& Choyce Ltd "Backgrounds for Modern Living" p 22; Ballantynes "Let your originality reflect" $\mathrm{p} 4$.

${ }^{37}$ Champion Ltd "Champion de luxe" p 4; L T Hayman Ltd. "Please the Ladies p 28.

${ }^{38}$ Andrews \& Clark "Furnishings" p 29.
Interior linings of ideal homes in Home $\mathcal{E}$ Building

The interior linings of the show homes that are depicted and described in Home $\mathcal{E}$ Building, largely reflect the architectural and lifestyle ethos promoted in the magazine. The clear editorial hand in the selection of these homes must be acknowledged as biasing the types of homes that are depicted, with most using what can be described as modern, simple, practical and/or hygienic linings for the floors, walls and ceilings. However, to fulfil the mission of appealing to a broad sector of society, a number of show homes using more traditional lining products and designs are also included.

\section{Floor Linings}

For the dining and living rooms, fitted "all over body carpets" appear more frequently in modernist and modern homes, and in the grander homes of the well-to-do, ${ }^{39}$ promoted for their ability to make the room appear larger and to exude an "air of quiet comfort." 40 While vacuum cleaners, required to clean fixed carpets, were increasingly available in

39 "American Colonial exterior" p 27; "A New Otakei home" p 25.

40 "An interesting house on a sloping site" p 22; Tecta "Orderliness" p 34. 
New Zealand in the 1930s, they were still a novelty and beyond the means of most. ${ }^{41}$ It is therefore not surprising that several homes still used a hard flooring material, such as polished wooden floorboards, parquet flooring, and cork tile, ${ }^{42}$ with ornamental rugs placed over these which could be taken outside and shaken. In terms of the colours and styles of both body carpets and rugs, there is a mix of plain colours in pastel shades, such as mushroom pink, ${ }^{43}$ bolder colours, such as brown and green, ${ }^{44}$ as well as highly pattern carpets in mottled, oriental or floral motifs. ${ }^{45}$

For bathrooms, kitchens, laundries and highuse areas such as hallways, a wide range of floor coverings were used. These include softer flooring products such as rubber and linoleum, and harder products such as

${ }^{41}$ There were 3,122 items associated with vacuum cleaner advertising in newspapers available through PapersPast between 1930 and 1939, compared with just 432 items between 1920 and 1929.

42 "The Lovely Home of Mr \& Mrs K B Myers" p 11;

"'Paragon"'" p 3; "Berrisville Flats" pp 14-15.

${ }^{43}$ Tecta "Orderliness" p 34; "'Paragon"'" p 11.

44 "Mr \& Mrs J S Fletcher's new home" p 9; Tecta

"Orderliness" p 34; "'Paragon"'" p 11.

${ }^{45}$ Champion Ltd "A modern kitchen serves a Champion" p 22; Pickmere "Sleep in Beauty" p 39. terrazzo (a type of engineered stone) and tiles. All are described as modern, durable, hygienic, and most appear to be available in a range of colours and designs. ${ }^{46}$ In terms of soft flooring, rubber flooring (available in sheets or tiles) was used in bathrooms of both flats ${ }^{47}$ and private residences, ${ }^{48}$ and in the higher-use entrances, staircases and landings of apartments, such as Wellington's Fountain Court and Auckland's Berrisville flats, due to its noise dampening qualities. ${ }^{49}$ In terms of colours and patterns, references are frequently made to "green rubber flooring," 50 with a black border applied around this in the home of $\mathrm{Mr}$ SEM Brown at Kohimarama Beach, and a golden brown shade at Berrisville Flats. ${ }^{51}$ Linoleum, despite being extoled for its "[reduced] expense and ease of maintenance," 52 was used in just two kitchens, in mottled black in a renovated kitchen and a mottled ivory, grey and red in the Woburn

46 "No 1 Room" p 41; BPL "Colourful, Economical Floor Tiling" p 34

47 "Garden Court" p 22.

48 "'Paragon"'" p 13; "An Interesting Reconstruction" p 16, "A brick home" p 12.

49 "Berrisville Flats" p 14; "Fountain Court" p 10.

50 "For Sun and View" p 16.

51 "Another Modern Seaside Home" p 15; "Berrisville Flats" p 14

${ }^{52}$ BPL "Colourful, Economical Floor Tiling" p 34. home of Mr and Mrs Ashford.53 "Building Products Flexible Tiles" were advertised for use in bathrooms and kitchens, and appear to be a soft and durable flooring material, potentially containing asbestos. ${ }^{54}$ In terms of harder floor finishes, glazed tiles and terrazzo were also used for bathroom floors in several homes and apartments. ${ }^{55}$ A product called "Eternit(e) Granite" was advertised by Auckland based company MC Stapleton \& Co and Hopkirk Timbers Ltd as a modern, indestructible and hygienic material for bathrooms that could be toned to suit different colour schemes. ${ }^{56}$ This product was produced by Atlas Asbestos, based in Canada. ${ }^{57}$ Quarry stone (presumably natural stone) was the only other floor lining that was encountered in one show home, being used in

${ }^{53}$ Gosset "Just a little beauty treatment" p 35, "'Paragon"'" p 11.

${ }^{54}$ Building Products Limited also manufactured "Insultiles," a product that has the visual characteristics of asbestos, MacLean Building Catalogue p 7.

55 "Cintra" p 20; "Mr \& Mrs J S Fletcher's New Home" p 10; "The Lovely Home of Mr \& Mrs K B Myers" p 12;

"Berrisville Flats" p 14.

${ }^{56}$ Hopkirk Timbers Ltd "Eternit Granite [advertisement]" p 17.

${ }^{57}$ Atlas Asbestos Ltd "Atlas Asbestos is best [advertisement]" p 7. 
the hallway of a house at Cheltenham Beach. ${ }^{58}$

\section{Wall Linings}

The almost unanimous use of flat lining boards, such as plasterboard and fibrous plaster, in living and dining rooms, bedrooms and hallways by the 1930s, provided a flat and even canvas for the decoration of the walls in either paint or wallpaper. A large proportion of the show homes were painted, showing a preference for this simple and plain wall finish in line with modern architecture. In almost all instances, the colours that were chosen were either light pastel shades, predominantly in pink, blue, green and apricot, ${ }^{59}$ or cream..$^{60}$ The reason given for the use of light coloured paints is that they increase the sense of space and provide a natural background for more colourful furnishings. ${ }^{61}$ While different colour schemes were selected for different rooms by some owners, ${ }^{62}$ others chose to carry the same colour scheme throughout the entire home; a

\footnotetext{
58 "A Two-Faced House" p 31.

59 "A French Colonial Home" p 9; "Another Modern

Seaside Home" p 15; "Modernised Georgian" p 22.

60 "An Interesting Home" p 22; "Another Modern Seaside Home" p 15.

${ }^{61}$ Pickmere "Inside the Doors" p 45.

62 "For sun and view" p 16
}

move applauded by the editors who stated "one would like to see a little less of the silly treatment of each room."63 Wallpaper was depicted and mentioned less frequently, with these generally being plain, textured or arranged in horizontal bands of two different single coloured papers, a popular fashion of the time. ${ }^{64}$ Only one home used an old style Regency patterned wallpaper. ${ }^{65}$ Two unusual wall linings in living rooms were glazed parchment, occurring in just two homes, and a wallcovering similar to American oilcloth, a type of thin vinyl, for a kitchen renovation. ${ }^{66}$

A variety of wall effects, other than the simple use of paint and wallpaper, were also mixed and matched. Timber panelling, a more traditional feature seen in bungalows, ${ }^{67}$ makes an appearance in hallways, living and dining rooms, either for the entire wall or portions of this. ${ }^{68} \mathrm{~A}$ timber effect was also achieved by using tinted or varnished plywood, either

63 "A Pair of Modern Houses" p 10.

64 "An Interesting Residence" p 9; "Residence of Mr

Tingey Esq" p 37.

65 "'"Paragon"'" p 9.

66 "A French Colonial Home" pp 9, 11; Gosset "Just a Little Beauty Treatment" p 35.

${ }^{67}$ Ashford The Bungalow in New Zealand pp 58-59.

68 "A Portfolio of Small Houses" p 26; "An English House" p 28. with thin timber panels covering the joints between the sheets, or the joints were left exposed to produce a "modern panelled effect." 69 Tinted particle board was also used to this effect in two homes, one choosing this in the children's bedrooms as this will "stand up to all the hard knocks it is sure to get from the extremely energetic young gentlemen."70 Insulation boards provided another medium through which to achieve the modern panelled effect, and included "Donnacona" or "Insul-board," the former being a wood pulp based product, ${ }^{71}$ with the latter potentially an asbestos fibre containing board manufactured by Building Products Limited. ${ }^{72}$ These boards were available in both a rough textured or smooth finish and could be uses as-is, stained or painted..$^{73}$ A textured and stippled effect on walls was also achieve using stucco plaster, either applied to solid brick or concrete walls, or to wallboards. This was predominantly used for the interior walls of flats, such as the Cintra and Grafton Road Flats, most likely due to its ability to hide knocks and

\footnotetext{
${ }^{69}$ Beatson "A Charming New Home" p 14.

${ }^{70}$ Beatson "A Charming New Home" p 15.

${ }^{71}$ Information from Donnacona board manufacturers pamphlet.

72 See footnote 54

${ }^{73}$ RBL "Donnacona" p 2
} 
imperfections. ${ }^{74}$ A unique feature of two homes was the use of mirror panelling, intended to increase the sense of space, above or surrounding the fireplace in the living room. ${ }^{75}$

A variety of wall linings and finishes were used for kitchens, bathrooms and laundries, including plasterboard, compressed fibre or asbestos board and fibrous plaster board. ${ }^{76}$ These were either finished in enamel paint, ${ }^{77}$ vitrolite (coloured glass sheets), ${ }^{78}$ or glass tiles, the latter in a variety of colours and combinations of these ranging from green, black, white, cream and golden buff. ${ }^{79}$

\section{Ceiling Linings}

Compared to the floors and walls, relatively few images focussed on the finishing of ceilings, or provided textual references to these. For the most part, ceilings were kept relatively plain through the use of flat panels

74 "Cintra" p 20; "Eighty-Seven: New Flats in Grafton Road" p 32.

${ }^{75}$ Pickmere "Inside the Doors" p 45; "Glassage" p 11.

${ }^{76}$ BETA "Hot-and-Cold" p 39.

77 "'Paragon'"' p 11; "Eighty-Seven: New Flats in Grafton Road" p 32.

78 "An English House" p 28

79 "An Interesting Residence" p 8; "Another Modern Seaside Home" p 15; "House on a Hill" p 13. in a range of materials, such as plaster and insulation board, with the joints either left exposed to achieve the modern panelled effect, plastered to achieve a flat ceiling, or with thin timber or plaster battens applied to provide a stronger relief. ${ }^{80}$ While traditional villa and bungalow ceiling finishes, like pressed metal "Wunderlich" panels and moulded plaster ceilings and cornices by the Carrara Ceiling Company were advertised, ${ }^{81}$ only one example of the use of plaster embellishments was found. ${ }^{82}$ The virtues of plain and unadorned ceilings were extoled in an article by architect RR Phillips as contributing to a sense of "airness and clean suitability." 83

\section{Interior linings in the "real homes" of New Zealanders}

The sample of homes of everyday New Zealanders show some, but by no means all, of the interior lining trends depicted in Home $\mathcal{E}$ Building. While elements of the minimalist and modern approach were adopted, such as

\footnotetext{
80 "Another Modern Seaside Home" p 15; "Residence on Sea Cliffs" p 12; "A New Otakei Home" p 25.

${ }^{81} \mathrm{H}$ C Clarke Ltd "Specialise in Permanent Roofing" $\mathrm{p}$ 42; G E Hunter Ltd "Enhance the Beauty" p 25.

82 "A Country House at Featherston" p 11.

${ }^{83}$ Philips "Some Thoughts on Home Building" p 48.
}

plain painted walls, body carpets and even full mirrored walls, more traditional linings of the bungalow and villa period, such as body and frieze wallpapered walls and match-lined kitchens, laundries and bathrooms, predominated.

\section{Floor Linings}

Aside from the "Best British rubber with a pattern" specified for the floor of the hallway and landings in the grand home of Mrs IB Bucholz, the non-service rooms of all other homes within the sample of building permits were lined with tongue and groove floorboards. Given that the specifications frequently stated for these to be covered during construction and/or sanded and oiled upon completion, indicates that these were the exposed flooring finish. This was also the base finish for one hall and six dining or drawing rooms in the sample of photographs where the floor was visible, with loose rugs used for six of these rooms. ${ }^{84}$ A central piece of patterned linoleum may be present in two

${ }^{84}$ Harvey. Interior of a private house (C.002734); Harvey. Interior of a private house (C.002736); Harvey. Interior of a private house (C.002737); Anon. Three people in a drawing room; Anon. Interior design (13-2206); Anon. Interior design (13-2263); Anon. Interior view; Leech, Interior of House; Ellis \& Burnand - kitchen interior. 
images of a dining and drawing room respectively, based on the smooth and slightly glossy appearance of the lining underneath the rug. ${ }^{85}$ All over body carpets can be seen in only two images, with a light and plain coloured carpet used in the drawing room of the Sutch residence in Wellington, and a square patterned carpet with floral motifs used for a hallway which is being proudly vacuumed by its owner. ${ }^{86}$

Sanded and polished tongue and groove flooring also predominates in the service rooms for almost all of the homes in the sample of building permits. Rubber flooring with a pattern is applied to the bathroom and/or separate toilet of only three homes, that of Mrs IB Bucholz, Mrs Johnston Esq and $\mathrm{Mr}$ and Mrs Craig, with a terrazzo floor in the shower of all but the latter. All three of these homes are in the upper brackets in terms of construction costs, potentially indicating the cost and associated status of this material. With regard to the kitchen, it is possible that linoleum or another type of applied flooring was added after the house was constructed, as this flooring finish is seen in two of the four

${ }^{85}$ Anon. Interior design (13-2206); Anon. Interior design (13-2263).

${ }^{86}$ Burt. Woman using a vacuum cleaner. photographs of kitchens, with either a marble or square patterned effect. ${ }^{87}$

\section{Wall Linings}

The trend for painted walls in living, dining and bedrooms propounded by Home $\mathcal{E}$ Building was only adopted in the sample of building permits by Mr Houri Esq for his Art Deco home, and for the master bedroom of $\mathrm{Mr}$ Johnston Esq residence in Moxham Avenue. The remainder of the living rooms, bedrooms and hallways were wallpapered, with cheaper wallpapers valued at 3 shillings per roll used in homes under $£ 1,025$, with 4 shilling rolls used in the living and dining rooms of some of these; and rolls valued above this specified in the remainder of the sample, with the most expensive wallpapers valued at 5 shillings specified for the homes of Mrs Bucholz and $\mathrm{Mr}$ Bullinger. Two of the homes, that of $\mathrm{Mr}$ Natoli and Mr Bullinger, also specified the use of a filling wallpaper with a different patterned frieze above this, being a trend popular in the late nineteenth and early twentieth centuries but one which continued into the 1930s to a limited extent. ${ }^{88}$ Half of the photographs showing living, dining and

\footnotetext{
${ }^{87}$ Burt. Kitchen interior; Gunson. Cat and kitchen.
} ${ }^{88}$ Arber Thirtiestyle p 5. bedrooms also used wallpapers, only two had all over plain or textured papers, ${ }^{89}$ with the remainder having floral and Asiatic patterned wallpaper, with two utilising the filling and frieze technique. ${ }^{90}$ The remainder of the photographs of living rooms had light coloured painted walls, with one adopting the mirrored wall effect shown in Home $\mathcal{E}$ Building for the entire wall surrounding the fireplace of the living room. ${ }^{91}$ The two images of hallways had either polished timber panelling with plastered walls above, or painted hardboard and batten panelling.

A wider range of wall linings were used for the service rooms, with almost all being finished in enamel paint. Traditional vertical match-lining was used in the kitchens of only two homes in the sample of building permits, ${ }^{92}$ and appears in two of the photographs. ${ }^{93}$ The remainder of the kitchens in the photographs and building permits were

${ }^{89}$ Harvey. Interior of a private house (C.002734); Harvey. Interior of a private house (C.002737).

${ }^{90}$ Anon. Interior design (13-2206); Anon. Interior design (13-2263); Anon. Interior design (13-2159); Leech, Interior of House.

${ }^{91}$ Bergman. House interior.

${ }_{92}$ Homes of Mr Houri Esq and Mrs Robertson.

${ }^{93}$ Ellis \& Burnand - kitchen interior; Burt. Kitchen interior. 
lined with a variety of enamelled hardboard, plywood or plaster-based panels, with an imitation tile hardboard of the "Cellotex" brand being used in AE Tilley's home to give the effect of the more expensive glazed tile walls for less. These types of wall finishes were also used within all of the bathrooms in the building permit sample, with AE Tilley and Mr Houri opting for the panels with imitation tile effects, with applied white glazed tiles used around the bathtub by the former. Match lining was used for the walls of the laundries in all but two homes, with enamel painted hardboard or plaster board specified in the homes of Mrs Bucholz and $\mathrm{Mr}$ Bennett.

\section{Ceiling Linings}

The ceilings in all of the bedrooms, living and dining rooms in the sample of building permits were painted plain or textured plaster, fibrous or hard boards, with battens in timber or plaster specified for most to cover the joints between the sheets, referred to as board and batten ceilings. In four instances, additional specifications were given for a design in the centre of the ceiling formed out of battens and finished with or without additional decorative features. Insulation board was specified for the home of $\mathrm{Mr}$ and
Mrs Craig, with square patterns cut into this, replicating the modern panelled effect used for some of the homes in Home \& Building. Of the eight ceilings that were visible in the nonservice rooms in the photographs, six were board and batten, with only the modern drawing rooms of the Sutch residence and that with the mirrored wall being plain ceilings. ${ }^{94}$

With regard to the service rooms, nine of the laundries had match-lined ceilings, either oiled or enamel painted, with the remainder being enamel painted plaster, insulation or hardboards. Only the ceiling of the kitchen of Mrs Robertson's home was match-lined, with the remainder being enamel painted plaster or hardboard. All of the bathroom ceilings were enamel painted plaster or hard boards. Only two ceilings were visible in the photographs of kitchens, with one being plain and the second board and batten. ${ }^{95}$

\section{Conclusion}

This case study, investigating a slice of 1930s New Zealand domestic interior fashions

${ }^{94}$ View of part of the Living room; Bergman, W.C. House interior.

${ }^{95}$ Burt. Kitchen interior; Ellis \& Burnand - kitchen interior. between late 1936 and 1939, has provided some interesting insights into the types of decorative linings used within both the "ideal" homes in the Home $\mathcal{E}$ Building magazine and the "real" homes of New Zealanders from a small selection of building permits and photographs.

The architectural and lifestyle ethos that the magazine propounded, with an emphasis on modern design, informal living, practicality, hygiene, and individual choice and expression, is shown in the decorative linings of the show homes. Linings such as all over body carpets, rubber flooring, light pastel and plain colour walls, enamel paint for service rooms, the modern panelled effect of sheet linings, and the use of such design features as mirrored walls, are evidence of this. Some of these features were picked up by the owners of the sample of homes that were investigated, mainly by those with expensive or mid-range homes and who chose a more modern design, such as $\mathrm{Mr}$ Houri Esq. Linings chosen included rubber flooring, enamel paint, mirrored walls and the use of modern panelling over match-lining in some of the kitchens. However, a large proportion of the homes in the sample, ranging from the elite residence of Mrs Bucholz to the lower cost 
homes, also utilised more traditional and practical linings such as polished tongue and groove flooring, timber panelled hallways, match-lined laundries and wallpapered living, dining and bedrooms. These indicate more conservative attitudes towards interior design, confirming lloyd-Jenkins' view that the 1930s were a time of domestic restraint and conservative tastes, ${ }^{96}$ which was no doubt a source of frustration to the editors of Home $\mathcal{E}$ Building and aspiring architects and designers.

\footnotetext{
${ }^{96}$ lloyd-Jenkins At Home p 65.
} 


\section{REFERENCES}

"American Colonial Exterior with Modern Interior: A Residence at Lowry Bay, Wellington" Home and Building (February 1938) 2(2):24-27. Andrews and Clark "Furnishings by Andrews and Clark

[Advertisement]" Home and Building (November 1938) 3(1):29.

Andrews and Clark "Striking the Notes That Give Harmony to Your Interiors [Advertisement]" Building Today (January 1937) 1(2):37.

"Another Modern Seaside Home at Auckland" Home and Building (February 1938) 2(2):15.

Arber, Katie Thirtiestyle London: Middlesex University Press, 2003.

Ashford, Jeremy The Bungalow in New Zealand Auckland: Penguin Books, 1994.

Atlas Asbestos Company "Atlas Asbestos Is Best [Advertisement]" The Newfoundland Journal of Commerce (February 1952) 19(2):7.

Ballantynes "Let Your Originality Reflect in the Furnishings of Your Home ... [Advertisement]" Home and Building (February 1939) 3(2):4.

Beatson, Ronald "A Charming New Home at Auckland" Home \& Building (November 1938):14-15.

Beatson, Ronald, and C. Irwin Crookes "Editorial" Building Today, (January 1937) 1(2):7.

Beatson, Ronald, and C. Irwin Crookes "Editorial" Home and Building (November 1937) 2(1):7.

Beatson, Ronald, and C. Irwin Crookes "Editorial" Home and Building (February 1939) 3(2):7.

"Berrisville Flats" Home and Building (May 1938) 2(3):14-15.

BETA "Hot-and-Cold" Building Today, (January 1937) 2(1):38-39.

Brand, Stewart How Buildings Learn: What Happens After They're Built London: Phoenix Illustrated, 1997.

"A Brick Home Overlooking the Auckland Harbour" Home and Building (August 1939) 3(4):11-12.
Brookes, Barbara "A Sense of Place" At Home in New Zealand: History, Houses, People ed Barbara Brookes. Wellington: Bridget Williams Books, 2000:1-3.

Brookes, Barbara, and Louise Shaw "Constructing Homes: Gender and Advertising in Home and Building, 1936-1970" New Zealand Journal of History (1999) 33(2):200-220.

Building Products Limited (BPL) "Colourful, Economical Floor Tiling [Advertisement]" Home and Building (November 1938) 3(1):34.

Champion Ltd "A Modern Kitchen Deserves a Modern Champion [advertisement]" Home and Building (February 1939) 3(2):22.

Champion Ltd "Champion de Luxe Streamlined Gas Cooker [Advertisement]" Home and Building (November 1938) 3(1):4.

"Cintra" Building Today (October/November 1936) 1(1):19-21.

Clark, Justine and Paul Walker "Book, House, Home" At Home in New Zealand: History, Houses, People Wellington: Bridget Williams Books, 2000:195-109.

Clark, Justine and Paul Walker Looking for the Local: architecture and the New Zealand modern. Wellington: Victoria University Press, 2000.

Cottrell, William Furniture of the New Zealand colonial era: An illustrated history, 1830-1900 Auckland: Reed, 2006.

"A Country House at Featherston" Home and Building (November 1938) 3(1):10-11.

Drummond, Alison \& Drummond, Leo Roderick At Home in New Zealand: An illustrated history of everyday things before 1865 Auckland: Latimer Trend and Co Ltd, 1967.

"Eighty-Seven: New Flats in Grafton Road, Auckland, for S Dadley Esq" Home and Building (November 1939) 4(1):32.

"An English House in Parnell" Home and Building (August 1938) 2(4):2829. 
Esse Ltd "Better Cooking! ... At Less Cost with Less Labour

[Advertisement]" Home and Building (February 1938) 2(2):14.

"Evolution or Revolution: What New Zealand Architects Are Doing with

Modernism" Building Today (October/November 1936) 1(1):13, 36, 43.

"For Sun and View" Home and Building (November 1939) 4(1):16-17.

"Fountain Court Flats" Home and Building (August 1939) 3(4):9-10.

"A French Colonial Home on the Banks of the River Avon" Home and Building (November 1938) 3(1):8-9.

G E Hunter Ltd "Enhance the Beauty of Your Fibrous Plaster Ceilings with a Cornice and Distinctive Design [Advertisement]" Home and Building (February 1939) 3(2):25.

"Garden Court - Mission Bay" Building Today (January 1937) 1(2):21-22.

"Glassage" Home and Building (November 1939) 4(1):10-11.

Gosset, Helen M "Just a Little Beauty Treatment" Home and Building (February 1939) 3(2):33-35.

Gosset, Helen M "Make Way for Modern" Home and Building (November 1939) 4(1):36-39.

Guthrie Bowron \& Co. Ltd "Life's All a Matter of Environment

[Advertisement]" Home and Building (November 1938) 3(1):35.

$\mathrm{H}$ Beecham \& Co Limited. Donnacona Insulating board, undated.

https://ia800902.us.archive.org/15/items/H.BeechamCo.Pty.Ltd/H.\%20

Beecham\%20\%26\%20Co.\%20Pty.\%20Ltd_text.pdf

H C Clarke Ltd. "Specialise in Permanent Roofing [Advertisement]" Building Today (October/November 1936) 1(1):42.

Homes of Mr Houri Esq and Mrs Robertson

Hopkirk Timbers Ltd. "Eternit Granite [Advertisement]" Home and Building (February 1938) 2(2):17.

"A House on a Hill, Which Overlooks Two Harbours" Home and Building (February 1938) 2(2):15-16.
"An Interesting Home on a Sloping Site" Home and Building (November 1938) 3(1):22-23.

"An Interesting Reconstruction" Home and Building (May 1938) 2(3):16.

"An Interesting Residence at Mt Eden, Auckland" Home and Building (February 1938) 2(2):8-9.

L T Hayman Ltd. "Please the Ladies: A Modern Kitchenette, a Modern Bathroom. NOW - a Modern Laundry [Advertisement]" Home and Building, (May 1939) 3(3):28.

Leach, Helen Kitchens: The New Zealand kitchen in the 20th Century Dunedin: Otago University Press, 2014.

Leonard, L., H. Perkins and D. Thorns "Presenting and Creating Home: The Influence of Popular and Building Trade Print Media in the Construction of Home" Housing, Theory and Society (2004) 21(3), 97-110.

lloyd-Jenkins, Douglas At Home: A century of New Zealand design Auckland: Godwit, 2004.

"The Lovely Home of Mr \& Mrs K B Myers, East Tamaki" Building Today (January 1937) 2(1):9-12.

Macdonald, Charlotte "Strangers at the Hearth: The Eclipse of Domestic Service in New Zealand Homes c1830s-1940s" At Home in New Zealand: History, Houses, People ed Barbara Brookes. Wellington: Bridget Williams Books, 2000: 41-56.

MacLean Reports Limited. MacLean Building Catalogue, 1945. https://archive.org/details/MacleanBuildingCatalogue/mode/2up?q=in sul-board

Milne \& Choyce Limited "Backgrounds for Modern Living [advertisement]" Building Today (November 1936) 1(1):22.

"Modernised Georgian in New Plymouth" Home and Building (February 1938) 2(2):22.

"A Modernised Homestead on the Otago Peninsula." Home and Building (August 1938) 2(4):31. 
"Mr \& Mrs J S Fletcher's New Home at Wadestown, Wellington" Home and Building (February 1939) 3(2):9-11.

"A New Otakei Home That Has Character and Dignity" Home and Building (August 1938) 2(4):24-25.

"No 1 Room: The Modern Kitchen Must Be Scientifically Planned" Building Today (November 1936) 1(1):41, 48.

"A Pair of Modern Houses at Auckland" Home and Building (May 1939) 3(3):9-13.

"'Paragon": The Home of Mr \& Mrs J Ashford Harris, at Lower Hutt" Home and Building (August 1938) 2(3):3, 8-11.

Petersen, Anna New Zealanders at Home: A Cultural History of Domestic Interiors 1814-1914 Dunedin: Otago University Press, 2001.

Philips, R. R. "Some Thoughts on Home Building" Home and Building (August 1938) 2(4):41, 48.

Pickmere, Alison "Inside the Doors" Home and Building (February 1938) 2(2):44-47.

Pickmere, Alison "Sleep in Beauty" Home and Building (November 1937) 2(1):39.

"A Portfolio of Modern New Zealand Homes" Building Today (October/November 1936) 1(1):24-27.

"A Portfolio of Small Houses" Building Today (January 1937) 2(1):24-27. Reese Bros. Limited (RBL) "Donnacona [Advertisement]" Home and Building (August 1938) 2(4):2.

"A Residence on Sea Cliffs" Home and Building (August 1938) 2(4):12-15.

"Residence of M Tingey Esq, Miramar, Wellington" Home and Building (May 1938) 2(3):37.

Tecta "Orderliness in Furnishings." Building Today, (January 1937) 1(2):3435.

"A Two-Faced House" Home and Building (February 1938) 2(2):28-31.

"[Untitled]" Building Today (January 1937) 1(2):3.

\section{Images}

Anonymous. Interior design of living room in domestic dwelling (1930s) Museum of Transport and Technology (MOTAT), Accession No: 132159. https://collection.motat.nz/objects/89850/interior-design-ofliving-room-in-domestic-dwelling

Anonymous. Interior design of living-dining room in domestic dwelling (1930s) Museum of Transport and Technology (MOTAT), Accession No: 13-2206. https://collection.motat.nz/objects/89897/interior-designof-living-dining-room-in-domestic-dwelling

Anonymous. Interior design of living-dining room in domestic dwelling (1930s) Museum of Transport and Technology (MOTAT), Accession No: 13-2263. https://collection.motat.nz/objects/89954/interior-designof-living-dining-room-in-domestic-dwelling

Anonymous. Interior view of a house (1930-1939) Auckland Council Libraries (ACL) Heritage Images. Record ID: 1370-U024-01

Anonymous. Three people in a drawing room (c1938) Alexander Turnbull Library (ATL), Wellington. Ref: 1/1-017566-F https://tiaki.natlib.govt.nz/\#details=ecatalogue. 157620

Bergman, W.C. House interior - living room (3 December 1939) Auckland Council Libraries (ACL) Heritage Images. Record ID: 1370-U024-04

Burt, Gordon H. Kitchen interior (c1938) Alexander Turnbull Library (ATL), Wellington. Ref: 1/1-015928-F https://tiaki.natlib.govt.nz/\#details=ecatalogue. 195465

Burt, Gordon H. Woman using a vacuum cleaner (e1930s) Alexander Turnbull Library (ATL), Wellington. Ref: 1/1-015757-F https://tiaki.natlib.govt.nz/\#details=ecatalogue. 483464

Ellis \& Burnand - kitchen interior (c1930). Hamilton City Libraries (HCL). Accession No: HCL-07365 https://heritage.hamiltonlibraries.co.nz/objects/4024/ellis-burnandkitchen-interior 
Gunson, Jessie Helen. Cat and kitchen, Totara Park, Manurewa, 1939. Auckland Council Libraries (ACL) Heritage Images. Record ID:

Footprints 03184

https://kura.aucklandlibraries.govt.nz/digital/collection/photos/id/377 $71 / \mathrm{rec} / 155$

Harvey, Maurice. Interior of a private house. Museum of New Zealand Te Papa Tongarewa. reg no: C.002734

https://collections.tepapa.govt.nz/object/120216

Harvey, Maurice. Interior of a private house. Museum of New Zealand Te Papa Tongarewa. reg no: C.002736

https://collections.tepapa.govt.nz/object/120220

Harvey, Maurice. Interior of a private house. Museum of New Zealand Te Papa Tongarewa. reg no: C.002737

https://collections.tepapa.govt.nz/object/120222

Leech, Interior of House (1937-1938) Swainson/Woods Collection, Puke Ariki and District Libraries. Accession No: SW1931-1940.10487.

https://collection.pukeariki.com/objects/88605/leech-interior-of-house

View of part of the Living room in the Sutch House (1938) Alexander

Turnbull Library (ATL), Wellington. Ref: PAColl-5870-1-08

https://tiaki.natlib.govt.nz/\#details=ecatalogue.352639 